\title{
Linking agricultural crop management and air quality models for regional to national-scale nitrogen assessments
}

\author{
E. J. Cooter ${ }^{1}$, J. O. Bash ${ }^{1}$, V. Benson ${ }^{2}$, and L. $\operatorname{Ran}^{3}$ \\ ${ }^{1}$ United States Environmental Protection Agency, Office of Research and Development, National Exposure Research Lab, \\ Research Triangle Park, North Carolina, USA \\ ${ }^{2}$ Benson Consulting, Columbia, Missouri, USA \\ ${ }^{3}$ University of North Carolina, Institute for the Environment, Chapel Hill, North Carolina, USA
}

Correspondence to: E. J. Cooter (cooter.ellen@epa.gov)

Received: 18 April 2012 - Published in Biogeosciences Discuss.: 29 May 2012

Revised: 10 September 2012 - Accepted: 14 September 2012 - Published: 19 October 2012

\begin{abstract}
While nitrogen $(\mathrm{N})$ is an essential element for life, human population growth and demands for energy, transportation and food can lead to excess nitrogen in the environment. A modeling framework is described and implemented to promote a more integrated, process-based and systemlevel approach to the estimation of ammonia $\left(\mathrm{NH}_{3}\right)$ emissions which result from the application of inorganic nitrogen fertilizers to agricultural soils in the United States. The United States Department of Agriculture (USDA) Environmental Policy Integrated Climate (EPIC) model is used to simulate plant demand-driven fertilizer applications to commercial cropland throughout the continental US. This information is coupled with a process-based air quality model to produce continental-scale $\mathrm{NH}_{3}$ emission estimates. Regional cropland $\mathrm{NH}_{3}$ emissions are driven by the timing and amount of inorganic $\mathrm{NH}_{3}$ fertilizer applied, soil processes, local meteorology, and ambient air concentrations. Initial fertilizer application often occurs when crops are planted. A statelevel evaluation of EPIC-simulated, cumulative planted area compares well with similar USDA reported estimates. EPICannual, inorganic fertilizer application amounts also agree well with reported spatial patterns produced by others, but domain-wide the EPIC values are biased about $6 \%$ low. Preliminary application of the integrated fertilizer application and air quality modeling system produces a modified geospatial pattern of seasonal $\mathrm{NH}_{3}$ emissions that improves current simulations of observed atmospheric particle nitrate concentrations. This modeling framework provides a more dynamic, flexible, and spatially and temporally resolved estimate of $\mathrm{NH}_{3}$ emissions than previous factor-based $\mathrm{NH}_{3}$ inventories,
\end{abstract}

and will facilitate evaluation of alternative nitrogen and air quality policy and adaptation strategies associated with future climate and land use changes.

\section{Background and introduction}

Nitrogen (N) is an essential element required for the growth and maintenance of all biological tissues, but human population growth and increased demands for energy, transportation and food have lead to dramatic increases in $\mathrm{N}$ production (Galloway et al., 2008). While beneficial in N-limited systems, excess $\mathrm{N}$ associated with these trends can adversely impact both terrestrial and aquatic ecosystems (Lovett and Tear, 2008). In addition to implications for ecosystem health and sustainability, atmospheric ammonia $\left(\mathrm{NH}_{3}\right)$ gas will neutralize atmospheric acids, most notably sulfuric and nitric acid, to form ammonium $\left(\mathrm{NH}_{4}^{+}\right)$aerosols, a major constituent of fine particulate matter $\left(\mathrm{PM}_{2.5}\right)$ (Nenes et al., 1999), which can negatively impact human health (Pope and Dockery, 2006), reduce visibility and affect atmospheric radiative forcing (Hertel et al., 2011). The USEPA Science Advisory Board (United States Environmental Protection Agency, 2011) and the European Nitrogen Assessment (Sutton et al., 2011) emphasize the need for integrated, multimedia and transdisciplinary approaches to communicate effectively the risks associated with key societal threats from excess reactive nitrogen. Linking an agro-ecosystem model that includes cropland management decisions with a regional air-quality model to simulate continental-scale, bi-directional 
$\mathrm{NH}_{3}$ fluxes marks a significant step forward towards a more systems-level framework for $\mathrm{N}$ assessment.

The 2008 United States Environmental Protection Agency (EPA) National Emissions Inventory (NEI) (http://www.epa. gov/ttn/chief/eiinformation.html) estimates that $83 \%$ of US $\mathrm{NH}_{3}$ emissions are associated with commercial crop and livestock production. Ammonia emissions originating from soils receiving commercial $\mathrm{N}$ fertilizer applications account for $33 \%$ of all agricultural $\mathrm{NH}_{3}$ emissions. This inventory was developed from a combination of emission factors and inverse modeling (Gilliland et al., 2006) that assumes unidirectional emission from soil and vegetation canopies; however, $\mathrm{NH}_{3}$ is known to exhibit bi-directional behavior (Sutton et al., 1995), and recent studies suggest that inclusion of bi-directional $\mathrm{NH}_{3}$ behavior will alter regional nitrogen budget simulations in ways that are important for ecosystem and human health (Dennis et al., 2010).

The bi-directional (i.e., compensation point) approach described in Sutton et al. (1998) and Nemitz et al. (2001) employs a resistance-based flux model that compares the equilibrium concentrations of $\mathrm{NH}_{4}^{+}$and $\mathrm{NH}_{3}$ in leaf apoplast to ambient $\mathrm{NH}_{3}$ air concentrations. Cooter et al. (2010) confirm that this same paradigm can simulate the measured magnitude and temporal variability of post-application inorganic fertilizer $\mathrm{NH}_{3}$ emissions from grain-corn soils in the US southern Coastal Plain. This approach promises to improve current unidirectional, factor-based inventories, but its national-scale implementation is challenging. The foremost challenge is development of fertilizer management information on the temporal and spatial scales needed to support the dynamic regional air quality models that are used to perform regional- and national-scale $\mathrm{N}$ budget analyses. This information should reflect a range of current and alternative farm management actions that will support analysis of $\mathrm{N}$ budget response to future policy and alternative climate conditions. In addition, since future climate may require innovative management adaptation strategies, these estimates must rely minimally on historical data (i.e., should be process-driven) and should respond to intra-annual, interannual and multidecadal weather and climate as well as land use and land cover changes. The discussion that follows describes the development of such a fertilizer simulation system, evaluates two key aspects of this system, and closes with an example of the integration of this information into a regional air quality model application with bi-directional ammonia flux.

\section{The Agricultural Fertilizer Modeling System}

The primary objective of fertilizer application in the US is to maximize economic return related to commodity production. Crop- and region-specific fertilizer management strategies are employed by farmers to meet this objective and so proper characterization of these strategies is critical. In addition, the post-application biogeochemical fate of the fer- tilizer is needed to properly link $\mathrm{NH}_{3}$ fertilizer application with evasion. Models that simulate the effect of both farm management practices and biogeochemical processes on soil nitrogen concentrations can be characterized as being process, empirical or semi-empirical process-based. Processbased models attempt to simulate processes at the most fundamental level and are extremely useful for basic research or exploratory site-specific studies that seek to better understand the nature of these processes. Empirical models simulate many of the same processes through parameterizations requiring less detailed input information. These models are appropriate for applications that ask broad, "whatif" questions. Semi-empirical process models use more detailed parameterizations based on process research, still support "what-if" scenario studies, but are detailed enough to highlight specific areas in need of additional process-level analysis. Given this characterization, the Environmental Policy Integrated Climate (EPIC) model was selected for this application.

EPIC is a semi-empirical biogeochemical process model originally developed by the United States Department of Agriculture (USDA) in the early 1980's to assess the effect of wind and water erosion on crop productivity (Williams et al., 1984, 2008). It is a daily time-step, field-scale model, where computational "fields" can extend up to 100 ha in area. In the beginning, EPIC's focus was the characterization of the physical processes associated with erosion in order to simulate management solutions that maximize crop production while reducing soil and nutrient losses. Model options included characterization of various tillage practices, e.g., conventional, reduced-till, no-till, contour plowing, and engineering changes such as the construction of terraces and the installation of tile drainage. It included a heat unit-driven, above- and below-ground plant growth model, soil hydrology and soil heat budgets for multiple soil layers of variable thickness. EPIC also contained an economic component that supported farm-firm economic budget analysis, including input costs, e.g., equipment amortization, fuel use/cost, supplemental nutrient cost and application, as well as production benefits in terms of biomass and yield.

In the mid-2000's, the soil organic matter model used in the CENTURY biogeochemical model was modified and incorporated into EPIC (Izaurralde et al., 2006; Parton et al., 1994; Vitousek et al., 1994). Details of these modifications and a description of $\mathrm{N}$ treatment is provided in Appendix A. Figure 1 illustrates the current EPIC biogeochemical configuration for $\mathrm{N}$ and carbon (C). As noted in Izaurralde et al. (2006), a unique aspect of EPIC is that it explicitly treats changes in the soil matrix (density, porosity and water retention) as well as changes in soil constituents, such as organic $\mathrm{C}$, thereby allowing feedback mechanisms to operate. In this way, EPIC is well-suited for simulation of scenarios such as land use, land management and climate change in which soil moisture supply and soil matrix properties vary concurrently. Simulation output frequency is user-specified, 


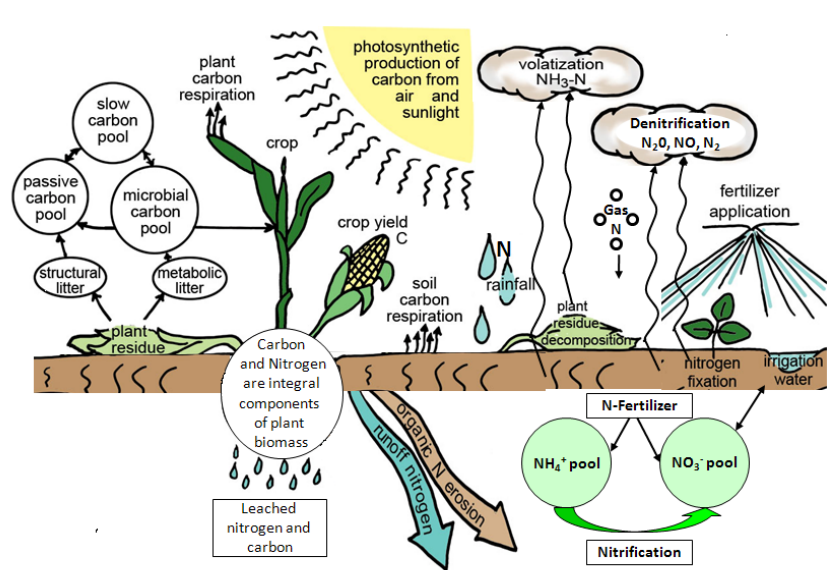

Fig. 1. Biogeochemical components of the carbon and nitrogen budgets in EPIC.

ranging from daily to annual summaries of biogeochemical process rates, nutrient pools and management activity. The current EPIC community code can be downloaded from http://epicapex.brc.tamus.edu. A relatively recent bibliography of EPIC publications is available at http://www.card. iastate.edu/environment/interactive-programs.aspx.

\subsection{EPIC inputs}

EPIC requires input information regarding soils, crop area, crop management and weather. Although our goal is to be as spatially explicit as possible, we recognize the limitations of available data and the spatial scale (regional) of the application. A multi-scale approach was adopted with crop management characterized at the coarsest scale $\left(\sim 10^{4} \mathrm{~km}^{2}\right)$, followed by crops and soil/hydrology $\left(\sim 10^{3} \mathrm{~km}^{2}\right)$, and weather $\left(\sim 10^{2} \mathrm{~km}^{2}\right)$. Rather than targeting behaviors of a specific, potentially unique, farm-firm that might have only a limited spatial scale of influence, this approach facilitates the characterization of broad trends in current and future crop management and fertilizer application practices that are likely to affect air quality and atmospheric deposition on regional to national scales. The target EPIC simulation resolution for integration with a gridded regional air quality model is $144 \mathrm{~km}^{2}$ i.e., $12 \mathrm{~km}$ by $12 \mathrm{~km}$ rectangular grid-cells.

\subsubsection{Crop management}

Figure 2 illustrates the USDA Farm Production Regions used to characterized EPIC management practices. Each region defines a geographic area in which crops and cropping practices are similar. The USDA National Agricultural Statistical Service (NASS) Agricultural Resource Management Survey (ARMS) (http://www.ers.usda.gov/Data/arms/) contains survey-based information regarding the number, type and general schedule of mechanical operations for each crop grown in each production area. In EPIC, the timing of mechanical operations, e.g., tilling, planting, harvesting are pre-

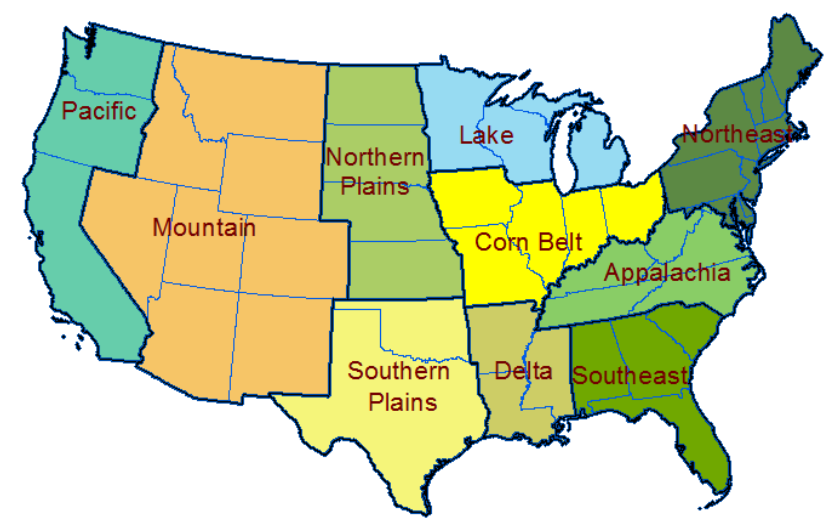

Fig. 2. USDA Farm Production Regions.

scribed by the user or are "scheduled" using accumulated heat units (HU) where:

$\mathrm{HU}=0.5 \times(\mathrm{TMX}+\mathrm{TMN})-\mathrm{TBSC} ; \quad \mathrm{HU}>0.0$.

Here HU is the number of heat units accumulated during a day, TMX and TMN are the maximum and minimum temperatures for the day, and TBSC is the crop-specific base temperature; all variables in ${ }^{\circ} \mathrm{C}$. A heat unit index (HUI) ranging from 0 at planting to 1.0 at physiological maturity is computed by accumulating daily $\mathrm{HU}$ values and dividing by the potential heat units of the crop. Resource additions such as fertilizer and irrigation can also be prescribed or triggered in response to "stress" conditions. EPIC modifies optimal plant growth and productivity by temperature, water, aeration, nutrient and aluminum toxicity stresses (Williams et al., 2008). The present application uses a combination of prescribed and automatically scheduled fertilizer and irrigation operations. The prescribed application approach is similar to that reported in Goebes et al. (2003), with some important differences that increase the physical detail as well as the temporal and spatial resolution of these scenarios. Appendix B contains a detailed description of this process.

Knowledge of the reactive $\mathrm{N}$ form applied and the method of application are important to the characterization of $\mathrm{NH}_{3}$ evasion dynamics. Table 1 provides an example of this information that has been developed for the present application (see Appendix B). While timing is indicated by "fall, spring and post-plant", specific application dates for each crop and model grid are estimated by EPIC. Overall, anhydrous ammonia is modeled as the $\mathrm{N}$ form of choice for US grain corn producers, but other forms also have a role, and the dominant form varies by time of year and geographic region. In the US Corn Belt (CB), $45 \%$ of annual grain corn $\mathrm{N}$ needs are met using anhydrous ammonia (injected liquid) in the spring, while only $15 \%$ of Lake States (LK) springtime grain corn N needs are met using this form. Forty percent $(40 \%)$ of Delta States' (DS) grain corn needs are met through spring application (incorporation) of urea. Nine percent $(9 \%)$ of Northern 
Table 1. Example of regional grain corn fertilizer amount, timing, form and distribution. Values are in percent of annual $\mathrm{N}$ needs met. LK = Lake States, CB = Corn Belt, NP = Northern Plains, SP = Southern Plains, DS = Delta States, SE = Southeast, AP = Appalachia, $\mathrm{NE}=$ northeast, $\mathrm{MN}=$ Mountain, $\mathrm{PA}=$ Pacific (see Fig. 2).

\begin{tabular}{|c|c|c|c|c|c|c|c|c|c|c|c|}
\hline \multirow{2}{*}{ Time } & \multirow{2}{*}{ Form } & \multicolumn{10}{|c|}{ Region } \\
\hline & & $\mathrm{NE}$ & $\mathrm{AP}$ & SE & LK & $\mathrm{CB}$ & DS & NP & SP & $\mathrm{MN}$ & PA \\
\hline \multirow{7}{*}{ Fall } & Anhydrous Ammonia & & & & 15 & 20 & & 25 & 20 & 30 & 30 \\
\hline & Ammonium nitrate & & & & & & & & & & \\
\hline & $28 \%$ solution & & & & 5 & & & & & & \\
\hline & $30 \%$ solution & & & & & & & & & & \\
\hline & other phosphate (DAP) & & 3 & & 3 & 3 & & 3 & & & \\
\hline & Urea & 10 & & & 15 & & & & & & \\
\hline & By Grade* & 5 & & 5 & & & 5 & & & & \\
\hline \multirow{7}{*}{ Spring } & Anhydrous Ammonia & & 50 & 10 & 15 & 45 & & 40 & 45 & 30 & 30 \\
\hline & Ammonium nitrate & & & & & & & & & & \\
\hline & $28 \%$ solution & & & & & & & & & & \\
\hline & $30 \%$ solution & 50 & & & & & & & & & \\
\hline & other phosphate (DAP) & & & 4 & 3 & 5 & 2 & 2 & 5 & & \\
\hline & By grade* & & & 35 & & & 30 & & & & \\
\hline & Urea & & & & & & 40 & & & & \\
\hline \multirow{8}{*}{ After Plant } & Anhydrous Ammonia & & & & & & 10 & & & 30 & \\
\hline & Ammonium nitrate & & & & & & & & & & \\
\hline & $28 \%$ solution & & & 10 & 10 & 20 & & & & & \\
\hline & $30 \%$ solution & & 30 & & & & & & & & 30 \\
\hline & $32 \%$ solution & 10 & 10 & 30 & & & 10 & 21 & 25 & & \\
\hline & Urea & & & & 5 & & & & & & \\
\hline & other phosphate (DAP) & & & & & & & & 1 & 3 & 3 \\
\hline & manure & 25 & 7 & 6 & 29 & 7 & 3 & 9 & 4 & 7 & 7 \\
\hline
\end{tabular}

* By grade $=$ blended fertilizer with NPK percentage specified.

Plains' (NP) states annual grain corn $\mathrm{N}$ needs are met using manure that is applied at or prior to planting (never after the crop has emerged). In contrast, $29 \%$ of Lake States' and $25 \%$ of Northeastern (NE) annual grain corn $\mathrm{N}$ demand are met through manure.

\subsubsection{Crops}

Table 2 lists the crops that are explicitly modeled for this application. A coarse, county-level spatial crop assignment is made using the USDA Census of Agriculture (http://www. agcensus.usda.gov/Publications). There are more than 3000 US counties ranging in size from $67 \mathrm{~km}^{2}$ in the Eastern US to $51800 \mathrm{~km}^{2}$ in the West. The 2001 United States Geological Survey (USGS) National Land Cover Database (NLCD) is used to provide additional spatial detail (http://landcover. usgs.gov/uslandcover.php) (Homer et al., 2007). This is a satellite product for the US that provides $30 \mathrm{~m}$ pixel-scale information for 29 aggregate land use categories. NLCD classes 81 and 82 (pasture/hay and cropland) are of particular interest for this application. Accuracy of this product is described in Wickham et al. (2010). In the future (post 2010), the US Department of Agriculture Crop Data
Table 2. Crops modeled within the Agricultural Fertilizer Modeling System (AFMS).

\begin{tabular}{ll}
\hline Grass Hay & Peanuts \\
Alfalfa Hay & Potatoes \\
Other grazed cropland and pasture & Rice \\
Barley & Rye \\
Canola & Sorghum for Grain \\
Edible Dry Beans & Sorghum for Silage \\
Edible Dry Peas & Soybeans \\
Corn for Grain & Winter Wheat \\
Corn for Silage & Spring Wheat \\
Cotton & Other crops \\
Oats & \\
\hline
\end{tabular}

Layer (CDL) (http://www.nass.usda.gov/research/Cropland/ SARS1a.htm) may offer even more detailed characterization of agricultural crop-species distribution. Land cover data for Canada and Mexico is estimated from the Moderate Resolution Imaging Spectroradiometer (MODIS; http://duckwater. bu.edu/lc/mod12q1.html). 


\subsubsection{Soil information}

The National Resources Inventory (NRI, http://www.nrcs. usda.gov/technical/nri) links crops to soils within 8-digit Hydrological Cataloging Units (sub-basins or HUCs). A HUC is a geographic area representing part or all of a surface drainage basin, a combination of drainage basins, or a distinct hydrologic feature. There are 21198 -digit HUCs in the conterminous US with an average extent of $\sim 3800 \mathrm{~km}^{2}$. For this application, only the dominant (with respect to area) soil associated with each crop is identified. The minimum soil inputs required by EPIC includes soil layer depth, bulk density, $\mathrm{pH}$, organic carbon, $\%$ sand, \% silt, calcium carbonate content and albedo. The nearest US soil is assigned to grid-cells in Canada and Mexico pending acquisition of more representative information.

Current soil structure information provided as input to EPIC may not reflect the desired land management scenario, and so EPIC is run for a 25 -yr spin-up period to allow nutrient pools and soil characteristics to adjust to the defined management environment. The average annual plant demand $\mathrm{N}$ determined during the last 5 -yr of this spin-up is used to guide fertilizer form scenario development and to provide initial conditions for simulation of year-specific weather. This ability to adjust the physical and chemical site characteristics to represent changing land use and cropping practices is critical to the modeling system's value for alternative-future analyses.

\subsubsection{Weather}

EPIC requires time series of radiation, maximum and minimum temperature, precipitation, mean relative humidity and mean $10 \mathrm{~m}$ wind speed conditions. These data can come from local observations, or may be simulated within EPIC. Daily precipitation is simulated after Nicks (1974), temperature and radiation follow Richardson (1982), wind speed and direction are modeled after Richardson and Wright (1984) and relative humidity is simulated as described in Williams (2008). Recommended practice for the spin-up simulation (see Sect. 2.1.3) is to use the weather simulator and the climatological characteristics of the closest weather station to each EPIC model grid-cell selected from a set of nearly 1000 historical locations. Results of the last 5-yrs of this spinup were used for system development, quality control and preliminary evaluation (see Sect. 3.0). In the future, yearspecific gridded weather conditions generated by numerical models such as the Weather Research Forecast Model (WRF) (Skamarock et al., 2008) will be used to ensure greater consistency between farm management and regional air quality models. In addition, time series of daily wet and dry deposition from these models will be input to explore the interplay between fertilizer $\mathrm{N}$ additions and atmospheric sources of $\mathrm{N}$.

\subsection{Example EPIC results}

Appendix $\mathrm{C}$ contains an example scenario created when Sect. 2.1 inputs are combined to describe the emission environment for grain corn in the Southeast production region. Figure 3 illustrates the 5-yr average EPIC-estimated date of first fertilizer application and inorganic $\mathrm{NH}_{3}$ application rate for winter wheat across the US. Winter wheat is planted in the fall, undergoes vernalization, resumes growth in the spring and then is harvested in the late spring or early summer. The grey areas in Fig. 3a indicate grid-cells in which the first fertilizer application is not simulated as occurring until after vernalization. Figure $3 b$ indicates the rate for all first applications for any grid-cell containing 16 or more ha of wheat. A value of zero indicates that wheat is reported in a grid-cell, but no fertilizer is applied.

\section{Continental-scale EPIC application and evaluation}

\subsection{Continental-scale application of EPIC}

This application assumes that each $12 \mathrm{~km}$ model grid-cell contains multiple EPIC monoculture "fields", but the location of each field within a grid-cell is spatially indeterminate. This approach has been shown to be adequate for modeling regional emission and transport of atrazine (Cooter and Hutzell, 2002a, b). As described in Sect. 2.1.2, agricultural area in a grid-cell is determined using the $30 \mathrm{~m} 2001$ NLCD data layer (classes 81 and 82), and the distribution of specific crops within these NLCD grid areas is determined using the USDA county crop statistics. Each $12 \mathrm{~km}$ grid-cell is assigned to a county polygon and is assumed to mirror that county's crop distribution. When a grid-cell spans multiple county polygons, the NLCD-determined agricultural area is assigned proportionally to each county, and the appropriate county crop distribution is applied to those area fractions. An EPIC field, then, is defined as the agricultural area assigned to a specific crop within a $12 \mathrm{~km}$ grid. There can be up to 42 "fields" (21 rainfed or irrigated crops, see Table 2) in a grid-cell. As noted in Sects. 2.1.1 and 2.1.3, specific crop and soil combinations vary by 8 -digit HUC, and crop-specific management varies on an agricultural production area basis. Grid-cell crop area is assigned to HUCs and farm production regions based on the proportion of area contained within a HUC or production region polygon, resulting in a suit of field-scale scenarios for each grid-cell. EPIC is then run for each crop scenario in each grid-cell across the full model domain ( $\sim 246000$ scenarios). These results are then areaweighted to aggregate grid-cell estimates of fertilizer inputs, which are then shared with the regional air quality model. 

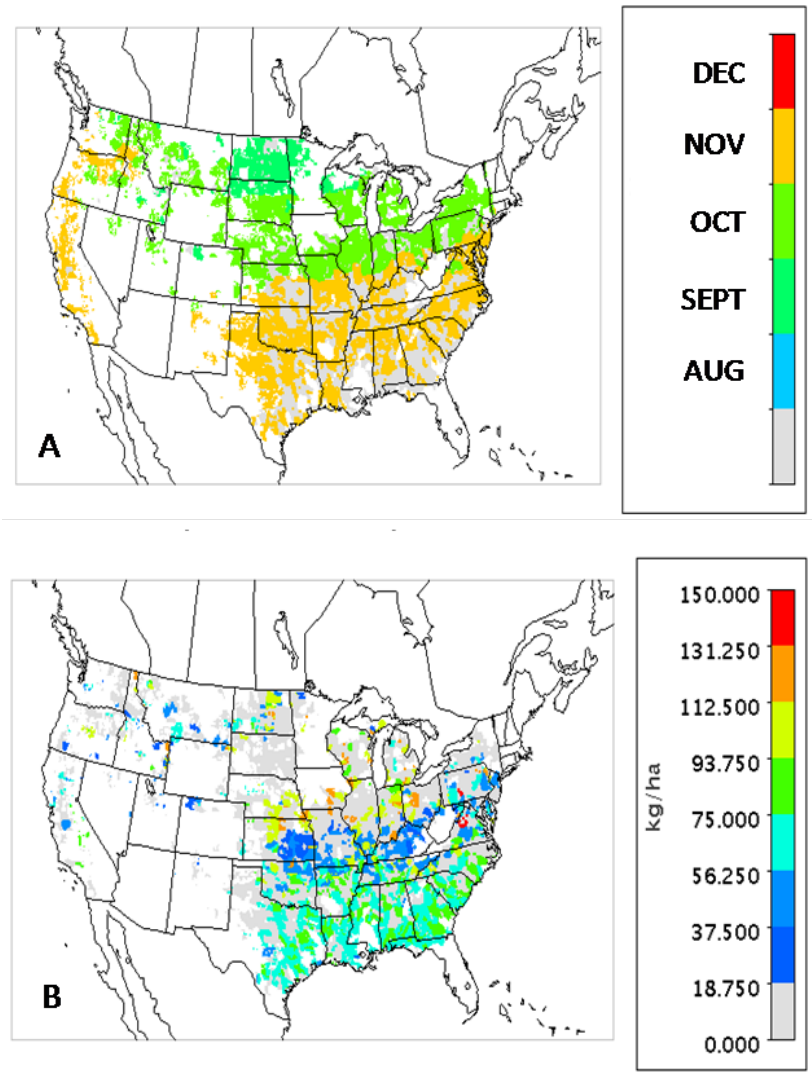

Fig. 3. EPIC simulated winter wheat (A) date of first fertilizer application and (B) rate applied on that date across the continental US.

\subsection{Fertilizer application timing evaluation}

Peak $\mathrm{NH}_{3}$ emissions are tightly coupled to the timing and amount of fertilizer application. Periodic national-scale management surveys report relative application timing, e.g., preplant, at plant, post-plant and the average number of applications, but date-specific application reports are rarely available. The most commonly available information for a variety of crops is date of planting and harvest. As stated previously, the majority of inorganic $\mathrm{N}$ is applied just prior to, or at planting so the proper characterization of this event is key. Harvest date, including the removal of some or all crop residue, impacts soil temperature and soil moisture, which influence subsequent nutrient transformations as well as rates and timing of fertilizer applied to fall-sown crops.

Weekly crop progress data, reported as a fraction of crop area within a state or county on which the operation has been completed, is available in digitized form from the National Agricultural Statistical Services (http://www.nass. usda.gov/Data_and_statistics/Quick_Stats). A reporting week runs from Monday through Sunday, with reports beginning the week ending the first Sunday in April (week \#13). First, the mean planting and harvest dates from the last 5 EPIC spin-up years for each grid-cell are assigned to crop progress weekly "bins." Next, the fraction of crop-specific area in each bin is estimated and is summed by creating a time series of cumulative planted area. Figure 4a illustrates 5-yr USDA-reported and EPIC-estimated cumulative planted area for rainfed grain corn in Iowa (Corn Belt) and rainfed winter wheat in Kansas (Northern Plains). Figure 4b shows a similar comparison for harvest dates. While Fig. $4 \mathrm{a}$ and $\mathrm{b}$ results show good agreement with observations, relationships for other crops and locations require further refinement. For instance, winter wheat in the US is grazed as well as harvested for grain. It is currently assumed that all simulated wheat is grown primarily for grain production. When wheat is intended to be grazed, it is planted 6 to 8 weeks earlier than wheat planted primarily for grain. In Fig. 4c, Texas planting dates appear to be simulated approximately 6 weeks later than observed, while harvest dates show good agreement with observations. This suggests an alternative management scenario is needed in this geographic region, i.e., the Southern Plains, in which wheat is grazed and, following vernalization, allowed to mature to be harvested for grain.

\subsection{Application rate evaluation}

A second key aspect of EPIC for use in process-based airquality models is the amount of fertilizer applied. This is explored through comparison of the EPIC simulation results to three alternative annual inorganic $\mathrm{N}$ application estimates. Figure 5a shows the distribution of EPIC 5-yr average annual fertilizer applications to agricultural lands in each US County based exclusively on crop $\mathrm{N}$ demand. A ca. 2002 time frame is a common US air quality baseline year and so it is used in this initial analysis. County total on-farm use is determined as shown in Eq. (2).

Use $=\sum_{i=1}^{n} \sum_{j=1}^{\text {crop }}\left(\mathrm{N}_{i j}-\right.$ manure $\left._{j}\right)\left(\mathrm{cf}_{i j}\right) 14400$

where Use is the county total inorganic $\mathrm{N}$ application in $\mathrm{kg}, n$ is the number of whole or partial model grid-cells assigned to the county, crop is the number of crops contained within the grid-cell, $\mathrm{N}_{i j}$ is the 5-yr average plant demand $\mathrm{N}$ in $\mathrm{kg} \mathrm{ha}^{-1}$, manure $_{j}$ is the portion of that demand met through manure application $\left(\mathrm{kg} \mathrm{ha}^{-1}\right)$ (e.g., Table 1$), \mathrm{cf}_{i j}$ is the fraction of the simulated $12 \mathrm{~km}$ grid-cell assigned to crop $j$ (adjusted for partial grid-cells) and 144000 ha grid $^{-1}$ is an area conversion constant. The total agricultural crop or pasture area in each grid-cell is constrained to NLCD land use classes 81 and 82 . These totals are fractionally distributed by crop species as suggested by the 2002 USDA Census of Agriculture. Open counties contain no agricultural or hay/pasture landuse (via NLCD). Figure $5 \mathrm{~b}$ and $\mathrm{d}$ show patterns of fertilizer use from the Ruddy et al. (2006) United States Geological Survey (USGS) analysis and the USEPA National Emissions Inventory (NEI). Both the USGS and USEPA estimates use Association of American Plant Food Control Officials (AAPFCO) 
A

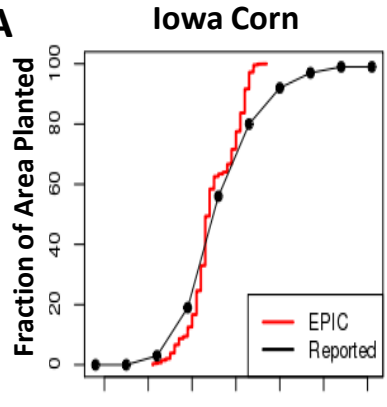

$\begin{array}{lllllll}100 & 110 & 120 & 130 & 140 & 150 & 160\end{array}$

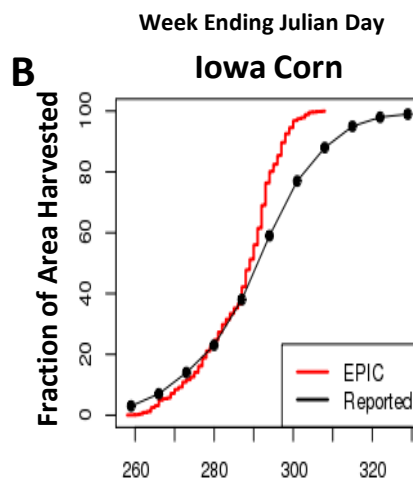

Week Ending Julian Day

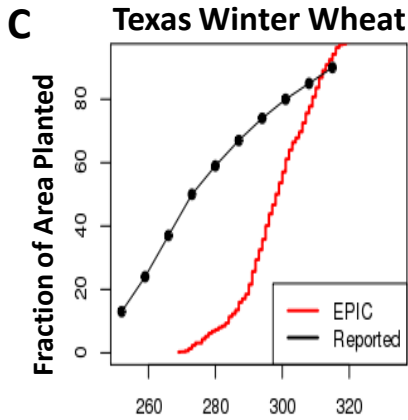

Week Ending Julian Day
Kansas Winter Wheat

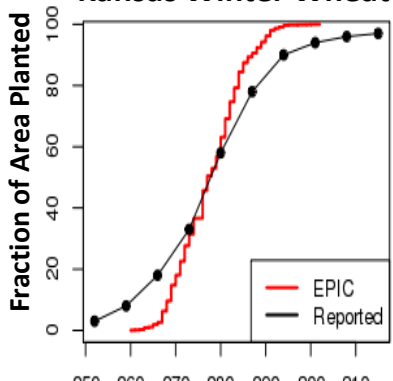

Week Ending Julian Day

Kansas Winter Wheat

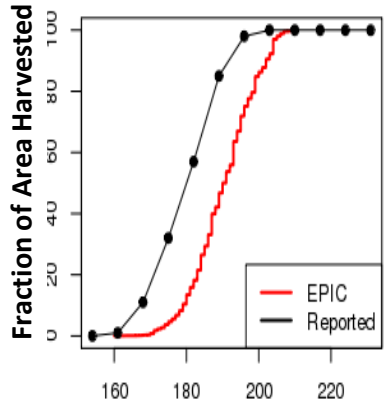

Week Ending Julian Day

Texas Winter Wheat

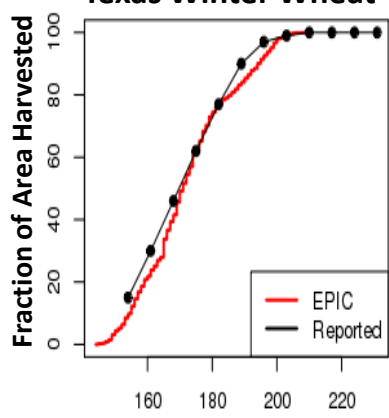

Week Ending Julian Day

Fig. 4. Example comparison of USDA operation completion dates to EPIC heat-unit based estimates for rainfed (A) Iowa corn and Kansas winter wheat planting, (B) Iowa corn and Kansas winter wheat harvest and (C) Texas winter wheat plant and harvest

data for direct farmer sales (e.g., AAPFCO, 2002), but each Agency processes these data differently. The USGS estimate (Fig. 5b) allocates the state-level AAPFCO data to counties using USDA Survey-based estimates of farmer fertilizer expenditures. If no farmer expenditures are reported, a valid value of zero is assigned. The USEPA estimates (Fig. 5d) are annual sums generated by Carnegie Mellon University (CMU) (Goebes et al., 2003) that have been reallocated to aggregate agricultural land use classes. The original CMU estimate uses county level AAPFCO reports for the 26 available states and the USGS state allocation method elsewhere. If no sales are reported for a county in a state that reports county sales, a value of zero is assigned to that county.
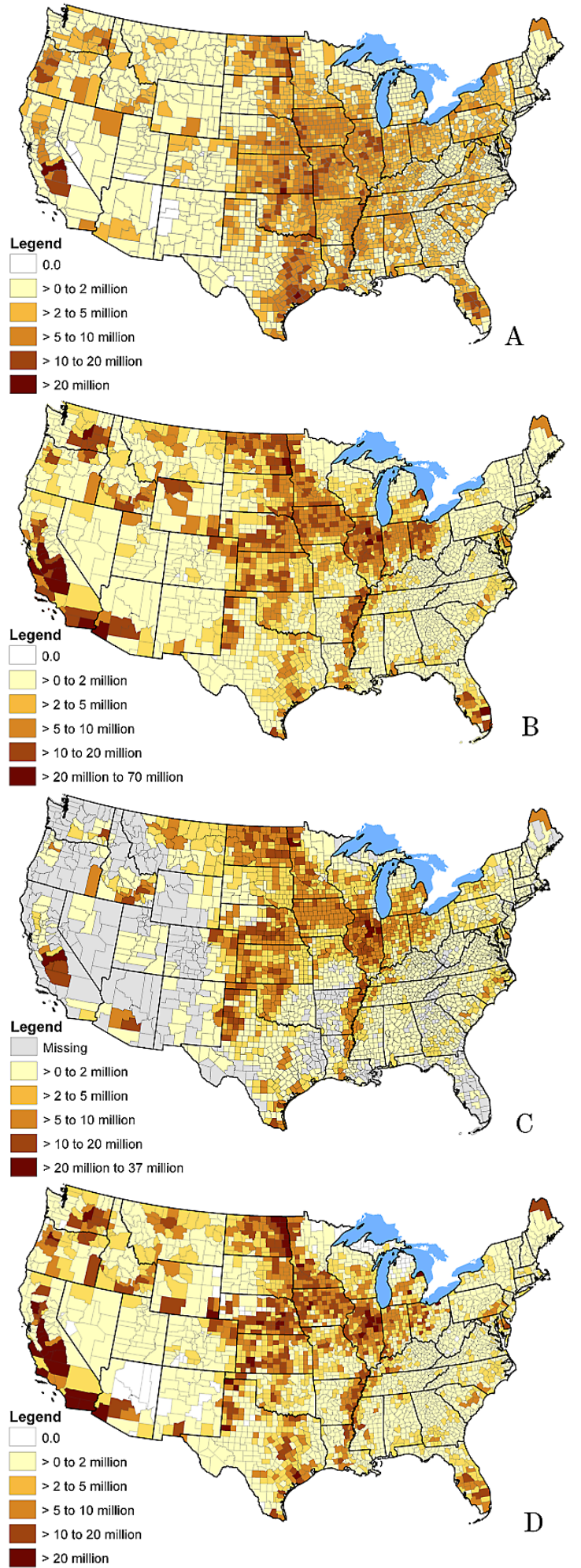

Fig. 5. (A) 5-yr average annual plant demand-based (i.e., EPIC) estimate of inorganic $\mathrm{N}$ use, (B) 2001 Inorganic N use Ruddy et al. (2006), (C) survey-based 1997 inorganic $\mathrm{N}$ use (NNLSCD; Potter et al., 2006) and (D) 2002 Inorganic N use (activity) as used in the US EPA National Emissions Inventory (Goebes et al., 2003). All values are kgN/county. 
The USEPA inventory does not distinguish between agricultural and non-agricultural fertilizer sales, and values shown in Fig. 5d include both sources. A domain-wide comparison of the USEPA and USGS values for farm plus non-farm use agree within about $6 \%$. Clearly, the USGS and USEPA estimates are not independent, and so a third survey-based estimate is provided. Figure 5c is based on the 1997 Agricultural Practice Survey (Potter et al., 2006). Gray areas in this map represent federally owned lands or areas in which there were too few survey responses to meet non-disclosure requirements.

The Fig. 5a geospatial pattern, based solely on simulated plant $\mathrm{N}$ demand, appears to be a reasonable hybrid solution of sales and survey results. Estimated N manure applications have been removed from the EPIC total to be commensurate with the other inorganic N estimates. Overall, EPIC results are about $7 \%$ below USGS domain-wide totals, but tend to be higher than USGS estimates in the Eastern US and lower than the USGS estimates in the West. Potential sources of these regional differences will continue to be explored and management scenarios further refined, but EPIC plant demand-based $\mathrm{N}$ use estimates are always expected to be less than sales-based estimates since farmer "overfertilization" action (to reduce production uncertainty) is not included. It is unclear that any one Fig. 5 estimate is inherently superior to another, but the EPIC rates appear to lie within the range of published estimate uncertainty (Sabota et al., 2012). The greatest advantage of the EPIC estimate over those derived from sales or survey-based information is that it is processdriven and does not rely on historical observation. This characteristic supports the use of EPIC to gage physically-driven $\mathrm{N}$ demand response to a variety of alternative environmental or policy scenarios that may or may not have historical analogs. Another means of determining the value of the EPIC estimates is to use them in an air quality modeling application, and to compare those results to atmospheric observations. An example of such an application is presented in Sect. 4.0.

\section{Coupling to a regional air quality model}

The system developed in Sect. 2 and evaluated in Sect. 3 provides management and process-driven inorganic $\mathrm{NH}_{3}$ fertilizer application rate, timing method of application and soil $\mathrm{pH}$ information at spatial and temporal scales appropriate for the bi-directional version of the Community MultiScale Air Quality (CMAQ) model version 5.0, which includes the Nemitz et al. (2001) two-layer resistance model for bi-directional $\mathrm{NH}_{3}$ exchange. A brief description of this implementation and example results are presented below. A more complete model description and presentation of results is provided in Bash et al. (2012).

The CMAQ 5.0 modeling system employs a 3-dimensional Eulerian modeling approach to address air quality issues such as tropospheric ozone, fine particles, acid deposition and visibility degradation (Byun and Schere, 2006). Traditionally, air quality models have addressed individual pollutant issues, such as urban ozone, regional acid deposition, particles, nitrogen, and toxics problems, separately. In contrast, the CMAQ modeling system is a comprehensive, stateof-the science, multiscale, multipollutant, "one atmosphere" system that includes a meteorological model to describe atmospheric conditions, emission models for anthropogenic and natural emissions that are released into the atmosphere, and a chemical-transport model (CTM) to simulate chemical transformations, atmospheric transport and fate. Most anthropogenic and biogenic emissions are parameterized as emission factors and activity rates, or are hourly estimates of temporally and spatially allocated emissions from point, nonpoint and mobile source inventories. Emissions from inorganic fertilizer applications were removed from the inventories when using the CMAQ $\mathrm{NH}_{3}$ bi-directional flux option to avoid double counting. The NEI estimates of animal feeding operation emissions are retained to characterize direct ammonia emissions from organic sources (manure). EPIC only models $\mathrm{NH}_{3}$ emissions derived from manure mineralization and subsequent nitrification of the mineralization product $\left(\mathrm{NH}_{4}^{+}\right)$. The CMAQ CTM parameterizes wet and dry deposition processes, transport due to horizontal and vertical advection and diffusion, and the dynamic partitioning of pollutants, including $\mathrm{NH}_{3}$, to fine and coarse aerosols. Changes in one pollutant can influence the concentrations and sinks of other pollutants directly or indirectly through chemistry, transport and aerosol processes.

An example of the coupling of daily EPIC output and processes for each CMAQ dynamic model time step $(\sim 5 \mathrm{~min}$ for $12 \mathrm{~km}$ grid spacing) with bi-directional exchange is shown in Fig. 6. Crop specific EPIC simulated inorganic $\mathrm{NH}_{3}$ fertilization rates, timing, method, and managed soil $\mathrm{pH}$ values are used to estimate $\left[\mathrm{NH}_{4}^{+}\right]$and the corresponding $\left[\mathrm{H}^{+}\right]$changes for each crop assigned to the NLCD agricultural area fraction of the grid-cell. The EPIC fertilizer application method information is used to allocate the fertilizer to the plow depth $(10 \mathrm{~cm})$ for injected or knifed-in applications or to the surface for spray or drip applications. These inputs are combined with the grid-cell crop distribution from BELD4, a standard CMAQ input data set that links NLCD-constrained Census of Agricultural crop areas to CMAQ grid-cells, and supports biogenic emission estimation for 230 natural and managed vegetation species. The result is a temporally and spatially detailed description of the increase in soil emission potential, $\Gamma_{\mathrm{s}}$, due to fertilizer application in agricultural land use categories. Following Walker et al. (2006), a nonagricultural $\Gamma_{\mathrm{s}}$ of 20 is used for other land covers. Ammonia evasion and $\mathrm{NH}_{4}^{+}$nitrification losses were modeled for CMAQ soil layers with depths of $1 \mathrm{~cm}$ and $10 \mathrm{~cm}$, leading to a dynamic, process-driven estimate of $\Gamma_{\mathrm{s}}$ temporal decay. Nitrification losses were modeled within CMAQ as in EPIC (Williams et al., 2008), and $\mathrm{NH}_{3}$ evasion was modeled using 


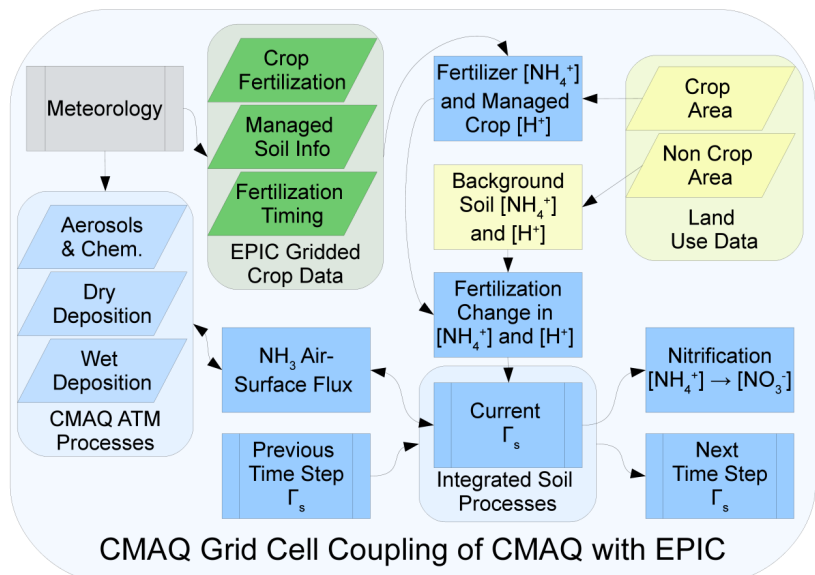

Fig. 6. Flow chart of EPIC coupled with CMAQ bi-directional $\mathrm{NH}_{3}$ exchange. Arrows represent the flow of information, meteorological processes are in grey, EPIC processes are shown in green, land use and land use derived data are shown in tan, and CMAQ processes are shown in blue.

the CMAQ bi-directional exchange based on the two layer resistance model of Nemitz et al. (2001). Ammonia fluxes and micrometeorological variables were calculated for each NLCD land use category, and then were aggregated to the grid-cell and weighted by the area of the land use categories from BELD4 to estimate the grid scale flux. Bi-directional exchange of $\mathrm{NH}_{3}$ in CMAQ conserves the mass of both atmospheric $\mathrm{NH}_{3}$ and the soil $\mathrm{NH}_{4}^{+}$concentrations for agricultural land use categories, and $\Gamma_{\mathrm{s}}$ is updated to reflect evasion, deposition and nitrification processes. The temporal dynamics of $\Gamma_{\mathrm{s}}$ following fertilization is driven by the evasive and nitrification losses of $\mathrm{NH}_{4}^{+}$in the soil rather than a decay time constant (Massad et al., 2010) or seasonal $\Gamma_{\mathrm{s}}$ factors (Zhang et al., 2010).

Figure 7a shows estimated annual bi-directional CMAQ $5.0 \mathrm{NH}_{3}$ emissions for 2002 compared to the factor-based USEPA NEI ammonia emissions estimates. Overall, CMAQ annual emissions are approximately one-half of the NEI estimates. The largest spring and fall emission reductions are largely in the Upper Midwest (Corn Belt), where precipitation biases resulted in an overestimation in the NEI $\mathrm{NH}_{3}$ emission estimate (Gilliland et al., 2006). Elsewhere, differences are driven by the timing of spring and fall fertilizer applications and temperature dependence of the compensation point in the bi-directional model. The changes in emissions were evaluated against ambient $\mathrm{NO}_{3}^{-}$observations because the largest changes in the emissions were in the early spring and late fall when the $\mathrm{NO}_{3}^{-}$aerosol is sensitive to changes in ambient $\mathrm{NH}_{3}$, and due to the lack of IMPROVE $\mathrm{NH}_{4}^{+}$and ambient $\mathrm{NH}_{3}$ observations (Pinder et al., 2008). Reductions in the estimates of the $\mathrm{PM}_{2.5}$ nitrate $\left(\mathrm{NO}_{3}^{-}\right)$aerosol concentration biases at urban Chemical Speciation Network (CSN, Fig. 7b) and rural Interagency
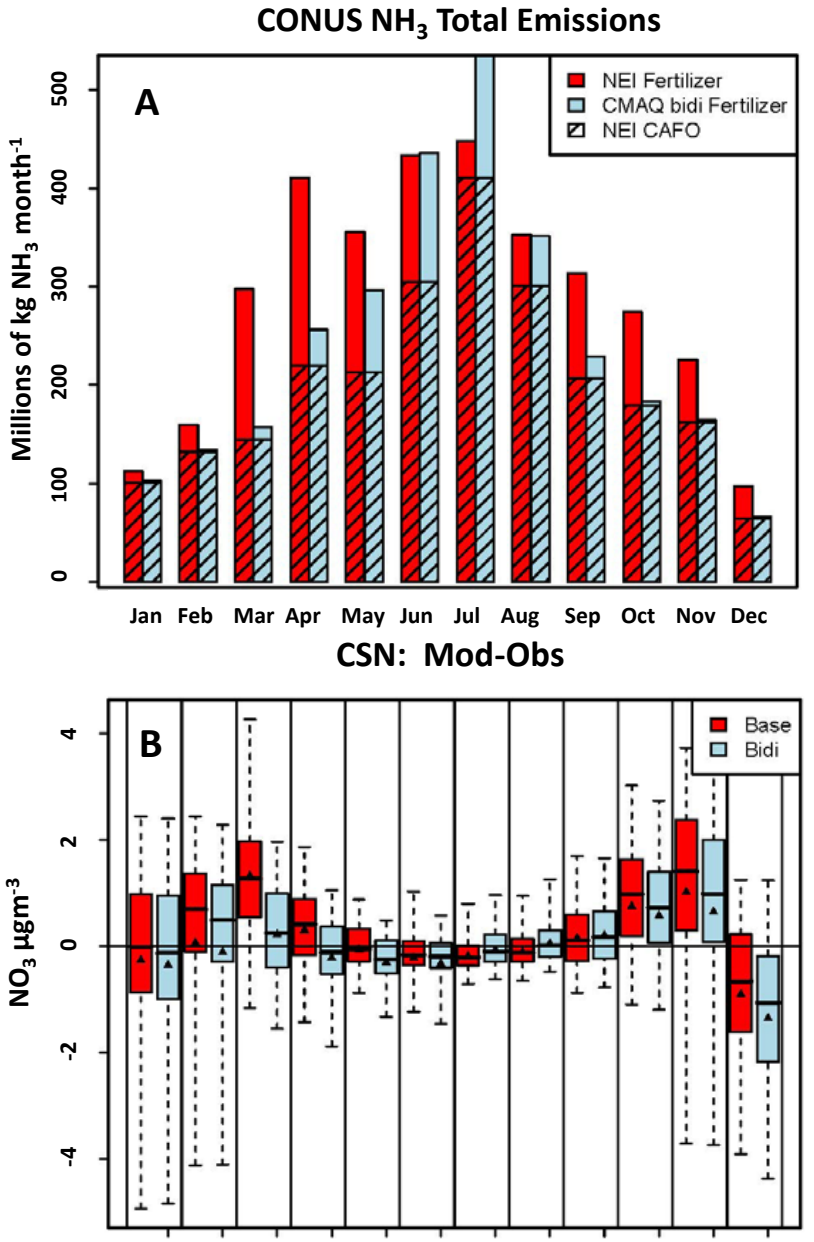

Jan Feb Mar Apr May Jun Jul Aug Sep Oct Nov Dec IMPROVE: Mod-Obs

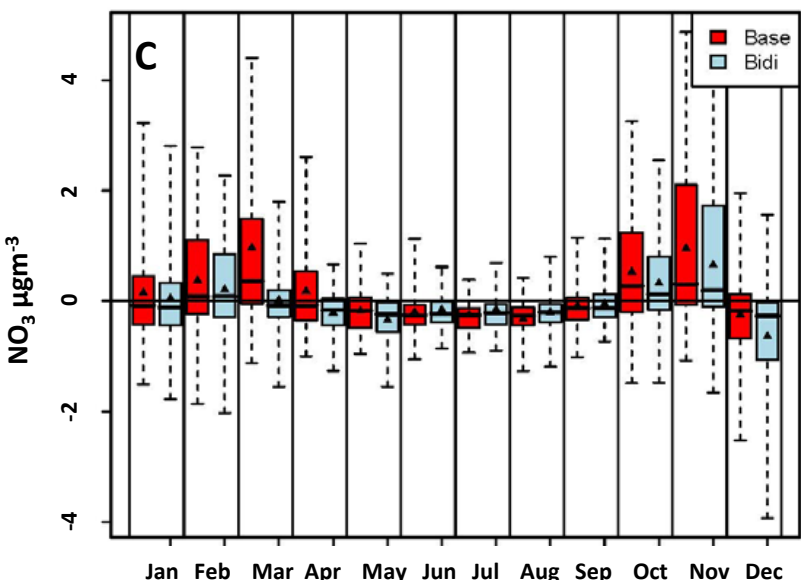

Fig. 7. (A) Monthly total $\mathrm{NH}_{3}$ emissions (Confined Animal Feeding Operations(CAFO), industrial, mobile, and inorganic fertilizer) reported in the 2005 US EPA NEI and estimated by the bi-directional CMAQ with EPIC fertilizer for the Continental US (CONUS), (B) monthly model ambient $\mathrm{NO}_{3}^{-}$biases for 2002 at urban CSN observation sites, and (C) rural IMPROVE observation sites. In (B) and (C), red indicates base model simulations and blue indicates bi-directional CMAQ with EPIC fertilizer, the black line within the box represents the median bias, shaded areas represent the range of the $25 \%$ to $75 \%$ quartile, the whiskers represent the range of $5 \%$ and $95 \%$ quantiles, and the black triangle represents the mean bias. 
monitoring of PROtected Environments (IMPROVE, Fig. 7c) sites support these shifts in the continental US $\mathrm{NH}_{3}$ emissions. CSN $\mathrm{PM}_{2.5}-\mathrm{NH}_{4}^{+}$observations were not included in this evaluation to be consistent with IMPROVE observations, and in recognition of the uncertainty that $\mathrm{PM}_{2.5}-\mathrm{SO}_{4}^{2-}$ model biases may add to the $\mathrm{PM}_{2.5}-\mathrm{NH}_{4}^{+}$evaluation. The similarity in the evaluation results at rural and urban sites indicates that $\mathrm{NH}_{3}$ emissions and deposition at rural/agricultural locations can impact regional $\mathrm{PM}_{2.5}$ concentrations. These bidirectional $\mathrm{NH}_{3} \mathrm{CMAQ}$ differences reflect the simulation of dynamic, weather-driven spring and fall application rates and dates in EPIC as opposed to fixed application rates and activity windows. Bidirectional exchange in CMAQ is a function of grid-cell specific weather and ammonia-ammonium Henry's Law and solubility equilibria conditions (Nemitz et al., 2000). Factor-based estimates, on the other hand, simulate emissions temperature response by imposing a fixed seasonal distribution and/or seasonal and spatial distributions based on inverse modeling that can incorporate model biases into the emission estimates. Further regional emission and aerosol estimate improvement is expected when CMAQ is provided with year-specific rather than 5-yr average EPIC inputs.

\section{Conclusions}

A methodology has been described that facilitates assessment of the process-driven regional-to-national response of agricultural soil emissions of $\mathrm{NH}_{3}$ to changing land use, policy and climate under a set of user-defined fertilizer management conditions and nationally consistent, spatially and temporally resolved inputs for the conterminous US. A preliminary evaluation of 5-yr average results suggests good agreement between simulated and observed timing of fertilizer applications at planting, and that regional and national patterns of sales and survey-based annual application rates are captured. Use of the temporal and spatial allocation approach such as those reported in Gobes et al. (2003) have supported ammonia emission inventory improvement over previous, static average values. The approach described here builds on this foundation by adding temporal and spatial detail through a flexible, process-based approach that explicitly includes human behavioral response i.e, management, to national policy and regional climate change analyses.

Future system improvements will include refinement of planting and harvest dates, expansion to year-specific weather conditions (to explore emission response to interannual weather variability), soil and management information for Northern Mexico and Southern Canada, and the addition of missing soil processes such as organic $\mathrm{N}$ mineralization to CMAQ. Massad et al. (2010) suggest that this process could be a significant factor controlling temporal patterns of $\Gamma_{\mathrm{s}}$ in some agricultural systems and inclusion of mineralization in CMAQ will provide a more complete systems- level characterization of $\mathrm{N}$ behavior in the environment. A user-friendly interface, the Fertilizer Emission Scenario Tool for CMAQ (FEST-C) is being developed to facilitate generation I/O API formatted inorganic $\mathrm{NH}_{3}$ fertilizer application rate information on a daily basis for the Continental US domain and a $12 \mathrm{~km} \times 12 \mathrm{~km}$ rectangular grid resolution. FEST-C should be released to the air quality modeling community through the Community Modeling and Analysis System (CMAS) Center by the close of 2012. At that time we anticipate FEST-C will support the generation of this information for any gridded US CMAQ domain and resolution for which consistent hourly weather and land cover information is available.

\section{Appendix A}

\section{EPIC biogeochemical treatment of $\mathrm{N}$ and $\mathrm{C}$}

EPICv0509 splits soil organic $\mathrm{C}$ and $\mathrm{N}$ into three compartments: microbial biomass, slow humus and passive humus (Williams et al., 2008). Organic residues added to the soil surface or below ground are split into metabolic and structural litter compartments as a function of $\mathrm{C}$ and $\mathrm{N}$ content. Following the CENTURY (Parton et al., 1994) approach, EPIC goes on to include: the use of linear partition coefficients and soil water content to calculate movement as modified by sorption, which are used to move organic materials from surface litter to subsurface layers; temperature and water controls affecting transformation rates are calculated internally in EPIC; the surface litter fraction in EPIC has a slow compartment in addition to metabolic and structural litter components; and lignin concentration is modeled as a sigmoidal function of plant age (Izaurralde et al., 2006). EPICv0509 has been modified further such that the upper 15 to $45 \mathrm{~cm}$ of the soil layer reflects the impact of specific tillage practices on biogeochemical process rates.

The $\mathrm{N}$ budget includes inputs from fertilizer application $\left(\mathrm{NH}_{3}\right.$ or $\mathrm{NH}_{4}^{+}$in solid or liquid form), $\mathrm{N}$ fixation by legumes and decaying organic matter, and will be modified to accept time series of wet and dry atmospheric deposition of oxidized and reduced $\mathrm{N}$. EPIC simulates the transformation of $\mathrm{NH}_{4}^{+}$to $\mathrm{NO}_{3}^{-}$through nitrification. Nitrate undergoes denitrification to produce $\mathrm{N}_{2}$ and $\mathrm{N}_{2} \mathrm{O}$, and organic $\mathrm{N}$ undergoes mineralization. Nitrogen is absorbed by plants, removed in harvested crops, and is dissolved in water or attached to particles that leave the field.

\section{Appendix B}

\section{Fertilizer Application Scenario Development}

In addition to USDA data bases and fertilizer sales data noted in Goebes et al. (2003), recommendations from knowledgeable agricultural experts are used to sensibly allocate 
phosphorus $(\mathrm{P})$ and $\mathrm{N}$. In most cases, the majority of $\mathrm{N}$ is applied immediately before or at crop planting. Prior to the growing season, a farmer has limited information regarding future market price and weather, so these decisions tend to be based on previous experience with the goal of maximum production, i.e., climatology. For each crop and US State, Goebes et al. (2003) assign a fixed pre-plant allocation, applied during a fixed window, lasting several weeks to 2 months, across all simulation years. For the present application, for each $12 \mathrm{~km}$ by $12 \mathrm{~km}$ grid-cell and crop, the amount of $\mathrm{N}$ initially applied is a fixed fraction of an annual EPIC 5yr climatological average amount, but the date of application will vary with crop, crop variety, local soil and weather conditions leading to more spatially and temporally resolved application estimates. The $\mathrm{N}$ form dictates the equipment used to apply the fertilizer, the depth of application and application timing, which in turn affects subsequent volatilization and other biogeochemical process rates as well as surface and sub-surface losses. The fraction-of-annual-total for each fertilizer form is distributed to meet crop $\mathrm{N}$ demand in a production region, based on documented crop management practices and yield value. For example, more costly $\mathrm{N}$ forms are assigned to higher-value crops. When crop demand exceeds inorganic agricultural $\mathrm{N}$ sales (AAPFCO, 2002), the shortfall is assumed to be met with manure. These estimates show good agreement with national estimates of regional organic (manure) $\mathrm{N}$ use by major commercial crops (Potter et al., 2006). Different manure sources exhibit different biogeochemical behaviors. For this application a single, dominant manure source is assumed for each production region, e.g., poultry litter in the Southeastern US, dairy manure in the Northeast, etc. The present scenario reflects market conditions for a base year, 2002, but economic model projections of fertilizer production costs, market prices, national policy directives, or alternative sales data could be used to modify these initial scenarios.

Goebes et al. (2003) assume that post-planting applications take place in a window 1 month after planting. Here, if a post-planting application is indicated by the fertilizer management scenario, e.g., Table 1, $\mathrm{N}$ is applied when the crop has reached $30 \%$ of maturity. The amount applied is defined as a region and crop-specific fraction of 5-yr average annual use. Subsequent post-planting fertilizer applications use the "automatic" option, with each application defined as a region and crop-specific fraction of 5-yr average annual use. The timing of each application will vary with local soil and weather conditions. This avoids the simulation of an unrealistic number of small fertilizer applications as well as too large an area receiving an application on the same day. If drought or other extreme conditions exist, such that crop $\mathrm{N}$ demand is minimal, no automatic application will occur. Additional applications are possible if $\mathrm{N}$ losses or crop demands are particularly high, but in most cases, applications cease once the crop has reached $50 \%$ of maturity.
Grain Corn Management Schedule

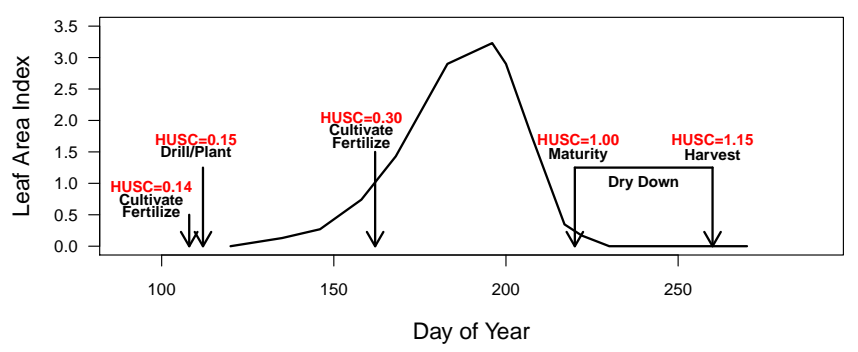

Fig. C1. Example EPIC grain corn management schedule for the North Carolina Coastal Plain. HUSC is the heat unit scheduling fraction.

Fertilizer is applied to hay/pasture areas receiving irrigation to support 3 cuttings per model year, while rainfed production systems are assumed to support one hay cutting, followed by livestock grazing. Stocking rates and subsequent manure introduction are determined for each model grid-cell as a function of potential evapotranspiration and precipitation. Fescue hay is simulated north of 35 degrees latitude or $1500 \mathrm{~m}$ elevation. Bermuda hay is simulated elsewhere.

\section{Appendix C}

\section{An example scenario}

Figure $\mathrm{C} 1$ presents an example of an EPIC management scenario for grain corn in a Southeastern Farm Production Area grid-cell. Prior to planting, heat units accumulate using a base temperature of $0^{\circ} \mathrm{C}$. On a climatological basis, there are 5710 annual base $0^{\circ} \mathrm{C}$ heat units for this grid-cell. Reasonable year-to-year operation date variability is simulated by referencing a particular year to climatological conditions. In this production area, corn farmers perform an initial cultivation prior to planting. Cultivation depth is $0.1 \mathrm{~m}$, with $30 \%$ soil mixing efficiency, resulting in a surface roughness of $20 \mathrm{~mm}$. Corn variety selection reflects the climatological growing season length. If soils are sufficiently warm for germination to occur, and are dry enough to support heavy machinery, corn is then planted (drilled) at a density of 6 plants $\mathrm{m}^{-2}$. A $10 \%$ soil mixing efficiency produces a surface roughness of $10 \mathrm{~mm}$. After the crop is planted, heat units are accumulated using a crop- and variety-appropriate heat unit base, in this case $8^{\circ} \mathrm{C}$. Additional operations are scheduled by comparing year-specific accumulations against a climatological time-to-maturity total, in this case 1680 . A second cultivation and fertilizer application are scheduled when $30 \%$ of growing season heat units have accumulated. The crop reaches maturity when the crop-specific heat unit sum reaches its climatological value (e.g., 1.0). For corn, an additional in-field dry-down period $(1680 \times 1.15)$ is simulated prior to harvest. 
Acknowledgements. The authors wish to thank Jimmy Williams, Senior Research Scientist, with the Texas AgriLife Blackland Research and Extension Center located at Temple, Texas for his continued interest and generous intellectual support of this work. We also wish to thank Joe Slater, Manager Fertilizer/AG Lime Control Services, University of Missouri Agricultural Experiment Station, Columbia, MO for his invaluable insights regarding fertilizer sales and use, and Ms Melanie Wilson of CSC, Raleigh, NC for graphics assistance. Portions of this research were completed with funding provided under US EPA contracts EP-D-07-102 and GS-35F-4381G, Task Order 1522. Although this work was reviewed by EPA and approved for publication, it may not necessarily reflect official Agency policy.

Edited by: S. Reis

\section{References}

AAPFCO: Commercial Fertilizers 2002, Washington DC, 2002.

Bash, J. O., Cooter, E. J., Dennis, R. L., Walker, J. T., and Pleim, J. E.: Evaluation of a regional air-quality model with bi-directional $\mathrm{NH}_{3}$ exchange coupled to an agro-ecosystem model, Biogeosciences Discuss., 9, 11375-11401, doi:10.5194/bgd-9-113752012, 2012.

Byun, D. W. and Schere, K. L.: Review of the governing equations, computational algorithms, and other components of the models3 Community Multiscale Air Quality (CMAQ) modeling system, Appl. Mech. Rev., 59, 51-77, 2006.

Cooter, E. J. and Hutzell, W. T.: A regional atmospheric fate and transport model for atrazine 1. Development and implementation, Environ. Sci. Technol., 36, 4091-4098, 2002a.

Cooter, E. J. and Hutzell, W. T.: A regional atmospheric fate and transport model for atrazine 2. Evaluation, Environ. Sci. Technol., 36, 4593-4599, 2002b.

Cooter, E. J., Bash, J. O., Walker, J. T., Jones, M. R., and Robarge, W.: Estimation of $\mathrm{NH}_{3}$ flux from managed agricultural soils, Atmos. Environ., 44, 2107-2115, 2010.

Dennis, R., Mathur, R., Pleim, J. E., and Walker, J. T.: Fate of ammonia emissions at the local to regional scale as simulated by the Community Multiscale Air Quality model, Atmos. Pollut. Res., 1, 207-214, 2010.

Galloway, J. N., Townsend, A. R., Erisman, J. W., Bekunda, M., Cai, Z., Freney, J. R., Martinelli, L. A., Seitzinger, S. P., and Sutton, M. A.: Transformation of the Nitrogen Cycle: Recent trends, questions, and potential solutions, Science, 320, 889-892, doi:10.1126/science.1136674, 2008.

Gilliland, A. B., Appel, K. W., Pinder, R. W., and Dennis, R.: Seasonal $\mathrm{NH}_{3}$ emissions for the continental United States: inverse model estimation and evaluation, Atmos. Environ., 40, 49864998, 2006.

Goebes, M. D., Strader, R., and Davidson, C.: An ammonia emission inventory for fertilizer application in the United States, Atmos. Environ., 37, 2539-2550, 2003.

Hertel, O., Reis, S., Skjoth, C. A., Bleeker, A., Harrison, R., Cape, J. N., Fowler, D., Skiba, U., Simpson, D., Jickells, R., Baker, A., Kulmala, M., Gyldenkaerne, S. G., Sorensen, L. L., and Erisman, J. W.: Nitrogen processes in the atmosphere, in: The European Nitrogen Assessment, edited by: Sutton, M. A., Howard, C. M., Erisman, J. W., Billen, G., Bleeker, A., Grennfelt, P., van Grinsven, H., and Grizzetti, B., Cambridge University Press, New York, 177-210, 2011.

Homer, C., Dewitz, J., Fry, J., Coan, M., Hossain, N., Larson, C., Herold, N., McKerrow, A., VanDriel, J. N., and Wickham, J.: Completion of the 2001 National Land Cover Database for the Conterminous United States, Photogramm. Eng. Rem. S., 73, 337-341, 2007.

Izaurralde, R. C., Williams, J. R., McGill, W. B., Rosenberg, N. J., and Quiroga-Jakas, M. C.: Simulating soil C dynamics with EPIC: Model description and testing against long-term data, Ecol. Model., 192, 362-384, 2006.

Lovett, G. M. and Tear, T. H.: Threats from Above: Air Pollution Impacts on Ecosystems and Biological Diversity in the Eastern United States, The Nature Conservancy and the Cary Institute of Ecosystem Studies, 2008.

Massad, R.-S., Nemitz, E., and Sutton, M. A.: Review and parameterisation of bi-directional ammonia exchange between vegetation and the atmosphere, Atmos. Chem. Phys., 10, 10359-10386, doi:10.5194/acp-10-10359-2010, 2010.

Nemitz, E., Sutton, M. A., Schjorring, J. K., Husted, S., and Wyres, G. P.: Resistance modelling of ammonia exchange above oilseed rape, Agr. Forest Meteorol., 105, 405-425, 2000.

Nemitz, E., Milford, C., and Sutton, M. A.: A two-layer canopy compensation point model for describing bi-directional biosphere-atmosphere exchange of ammonia, Q. J. Roy. Meteor. Soc., 127, 815-833, 2001.

Nenes, A., Pilinis, C., and Pandis, S. N.: Continued development and testing of a new thermodynamic aerosol module for urban and regional air quality models, Atmos. Environ., 33, 15531560, 1999.

Nicks, A. D.: Stochastic generation of the occurrence, pattern, and location of maximum amount of daily rainfall, Proc. Symp. Statistical Hydrology, Aug-Sep 1971, Tucson, AZ, USDA Misc. Publ No. 1275, 1974.

Parton, W. J., Ojima, D. S., Cole, C. V., and Schimel, D. S.: A general model for soil organic matter dynamics: Sensitivity to litter chemistry, texture and management, in: Quantitative Modeling of Soil Forming Processes, SSSA Spec. Public. No. 39 SSSA, Madison, WI, 147-167, 1994.

Pinder, R. W., Dennis, R. L., and Behave, P. V.: Observable indicators of the sensitivity of $\mathrm{PM}_{25}$ nitrate to emission reductions - Part I: derivation of the adjusted gas ratio and applicability at regulatory-relevant time scales, Atmos. Environ., 42, 1275-1286, 2008.

Pope, C. A. and Dockery, D. W.: Health effects of fine particulate air pollution: Lines that connect, J. Air Waste Manage., 56, 709742, 2006.

Potter, S. R., Andrews, S., Atwood, J. D., Kellogg, R. L., Lemunyon, J., Norfleet, L., and Oman, D.: Model Simulation of Soil Loss, Nutrient Loss, and Change in Soil Organic Carbon Associated with Crop Production, Natural Resources Conservation Service, US Department Agriculture, Conservation Effects Assessment Project (CEAP), Government Printing Office, Washington DC, 235 pp., 2006.

Richardson, C. W.: Dependence structure of daily temperature and solar radiation, Trans. ASAE, 25, 735-739, 1982.

Richardson, C. W. and Wright, D. A.: WGEN: A model for generating daily weather variables (ARS-8), Agricultural Research Service, 1984. 
Ruddy, B. C., Lorenz, D. L., and Mueller, D. K.: County-level estimates of nutrient inputs to the land surface of the conterminous United States, 1982-2001, US Geological Survey, Reston, VA, 2006.

Sabota, D., Compton, J., and Harrison, J.: Reactive nitrogen in the United States: How certain are we about sources and fluxes, Front. Ecol. Envrion., in press, 2012.

Skamarock, W. C., Klemp, J. B., Dudhia, J., Gill, D. O., Barker, D. M., Duda, M. G., Huang, X.-Y., Wang, W., and Powers, J. G.: A description of the Advanced Research WRF Version 3, National Center for Atmospheric Research Boulder, 125, 2008.

Sutton, M. A., Schjorring, J. K., and Wyers, G. P.: Plant-atmosphere exchange of ammonia, Philos. T. R. Soc. Lond., 351, 261-278, 1995.

Sutton, M., Burkhardt, J. K., Guerin, D., Nemitz, E., and Fowler, D.: Development of resistance models to describe measurements of bi-directional ammonia surface-atmopshere exchange, Atmos. Environ., 32, 473-480, 1998.

Sutton, M., Howard, C., Erisman, J., Billen, G., Bleeker, A., Grennfelt, P., van Grinsven, H., and Grizzetti, B. The European Nitrogen Assessment, Cambridge University Press, Cambridge, 612, 2011.

United States Environmental Protection Agency: Reactive Nitrogen in the United States: An analysis of inputs, flows, consequences, and management options (EPA-SAB11-013), Office of the Administrator, Science Advisory Board (SAB), available at: http://yosemite.epa.gov/sab/ sabproduct.nsf/67057225CC780623852578F10059533D/

\$File/EPA-SAB-11-013-unsigned.pdf (last access: August 2012), 2011.
Vitousek, P. M., Turner, D. R., Parton, W. J., and Sanford, R. L.: Litter decomposition on the Mauna Loa environmental matrix, Hawaii: patterns, mechanisms, and models, Ecology, 75, 418429, 1994.

Walker, J. T., Robarge, W., Wu, Y., and Meyers, T. P.: Measurement of bi-directional ammonia fluxes over soybean using the modified Bowen-ratio technique, Agr. Forest Meteorol., 138, 54-68, 2006.

Wickham, J. D., Stehman, S. V., Fry, J. A., Smith, J. H., and Homer, C.: Thematic accuracy of the NLCD 2001 land cover for the conterminous United States, Remote Sens. Environ., 114, 12861296, 2010.

Williams, J. R., Jones, C. A., and Dyke, P. T.: A modeling approach to determining the relationship between erosion and soil productivity., Trans. ASAE, 27, 129-144, 1984.

Williams, J. R., Izaurralde, R. C., and Steglich, E. M.: Agricultural Policy/Environmental eXtender Model: Theoretical Documentation Version 0604, Texas AgriLIFE Research, Texas A \& M University, Temple, TX, available at: http://epicapex.brc.tamus.edu, 2008.

Zhang, L., Wright, L. P., and Asman, W. A. H.: Bi-directional airsurface exchange of atmospheric ammonia: A review of measurements and a development of a big-leaf model for applications in regional-scale air-quality models, J. Geophys. Res., 115, D20310, doi:10.1029/2009JD013589, 2010. 